\title{
Markus Rheindorf and Ruth Wodak (eds.): Sociolinguistic Perspectives on Migration Control, Language Policy, Identity and Belonging
}

\author{
Multilingual Matters, Bristol, 2020, viii + 172 pp, Pb. £25, ISBN \\ 978-1-78,892-466-5
}

\section{Florian Coulmas ${ }^{1}$}

Received: 10 February 2021 / Accepted: 22 February 2021 / Published online: 8 April 2021 (c) The Author(s) 2021

This book tackles the "crisis in migration policy", which, as the editors note, in political circles and the mass media is commonly known as a "refugee crisis", especially that associated with the 2015 arrival in Europe from war-torn Syria, Afghanistan and Iraq. From this denomination in the very first sentence of the book it is clear where the editors stand. The crisis, if there is one, is with many countries' immigration regime rather than with the immigrants.

The seven chapters of the book address immigration control issues in several European countries, in Israel and in the US where the new nationalism, which is a prominent theme running through the book, has been given the material form of a wall at the Mexican border. Except in Chapter 6, about "Fortress Europe" by the editors, who combine corpus linguistics and discourse analysis, the reader will find few numbers in the book because overall the authors have adopted qualitative rather than quantitative approaches for the analysis of sociolinguistic, political, and language policy issues relating to migration control.

Both long-distance migration, for example, from Thailand to Israel, as is discussed Chapter 7, and intraregional migration, for example, between Yugoslavian successor states, addressed in Chapter 2, are discussed. Notwithstanding the many differences between the migration processes, as is demonstrated with regard to security issues, culturalization and symbolic politics in Chapter 1, the underlying motivations, and the researchers' interest in them, the logic of homogeneity and keeping culturally discordant migrants out surfaces in one form or another in all chapters. Culturally discordant does not mean all that much, unless someone decides that a group of newcomers should be so labelled, as the editors discuss in their introductory chapter. That the perceived

Florian Coulmas

florian.coulmas@uni-due.de

1 IN-EAST Institute for East Asian Studies, University of Duisburg-Essen, 47048 Duisburg, Germany 
discordance could be equally well attributed to people from just $200 \mathrm{kms}$ further south sporting a slight accent that does not inhibit communication (but gives them away), and to people from halfway around the world whose first language is completely unrelated to the locally dominant one, is remarkable.

As one might expect from a project in which Ruth Wodak is involved, discourse analysis and the study of narrative storytelling occupy a prominent place in the book, which brings together strategies of contesting discrimination, for instance in the UK and Pakistan (Chapter 3), narratives about immigrants' experience with migration control measures and popular media representation of immigrants in the US (Chapter 4), the meaning of the concept of diaspora in an increasingly fluid and diverse world (Chapter 5), and linguistic landscape analysis in the context of the politics of labour migrants' recruitment (Chapter 7). Citizenship, legal procedures, assimilation pressure, exclusionary identity politics, as well as language requirements and ideologies are other prominent topics discussed in several chapters of the book in relation to the concrete experiences of both people on the move and those who find themselves in a long-lasting state of uncertainty with respect to where or whether they belong.

Belonging, this is taken for granted without much discussion, is important, and, accordingly, exclusion and inclusion, discrimination and acceptance are illustrated with many examples, and no uncertainty is left as to where rejecting attitudes migrants often confront come from: right-wing politics and populist ideologies.

The book rides the identity wave that has engulfed the social sciences in Western countries for some time. The term appears in the title of the book and is referenced 33 times in the index. In some instances, it is used thoughtfully and comprehensibly, but not throughout. When, for instance, "in-between identities" (p. 92) appear on the scene, the reader wonders whether identities are a problem for migrants or for social scientists who have uncritically embraced the identity ideology of Western modernity.

There are some other surprising details mentioned in the book, for example, "a sixmonth period from January to April 2012" (p. 48). We are living in the age of space-time compression, true, but how this is possible remains the editors' secret. Other than that, the book makes for good reading and is a valuable contribution to the ongoing debate about migration to Western countries. The many actual examples of migration stories will be appreciated by all readers who don't think that ubi panis ibi patria is a shameful and condemnable motto and immigrants, refugees, asylum-seekers, undocumented migrants, and however they are categorized should go back to where they came from.

Funding Open Access funding enabled and organized by Projekt DEAL.

Open Access This article is licensed under a Creative Commons Attribution 4.0 International License, which permits use, sharing, adaptation, distribution and reproduction in any medium or format, as long as you give appropriate credit to the original author(s) and the source, provide a link to the Creative Commons licence, and indicate if changes were made. The images or other third party material in this article are included in the article's Creative Commons licence, unless indicated otherwise in a credit line to the material. If material is not included in the article's Creative Commons licence and your intended use is not permitted by statutory regulation or exceeds the permitted use, you will need to obtain permission directly from the copyright holder. To view a copy of this licence, visit http://creativecommons.org/ licenses/by/4.0/. 
Publisher's Note Springer Nature remains neutral with regard to jurisdictional claims in published maps and institutional affiliations.

Florian Coulmas is Senior Professor of Japanese Society at the IN-EAST Institute of East Asian Studies, University of Duisburg-Essen. 